\title{
Diel patterns of ammonium excretion and grazing rhythms in Calanus helgolandicus in surface stratified waters
}

\author{
Roger P. Harris ${ }^{1} \&$ Alenka Malej $^{2}$ \\ ' Marine Biological Association, The Laboratory, Citadel Hill, Plymouth PL1 2PB, United Kingdom \\ ${ }^{2}$ Morski raziskovalni in izobraževalni center, Inštitut za biologijo Univerze v Ljubljani, 66330 Piran, JLA 65, Yugoslavia
}

\begin{abstract}
Samples of adult female Calanus helgolandicus were collected at midday and midnight from the upper $20 \mathrm{~m}$ of the stratified water column in the western English Channel over $3 \mathrm{~d}$ in July 1983. There were pronounced diel changes in population density in these samples consistent with vertical migration through the thermocline; such migration was detected at the same station in September 1979 and August 1982. Ammonium excretion rates of the surface populations at midday and midnight were compared in short-term incubation experiments and additional samples taken for estimation of gut pigment, and the activity of the digestive enzymes amylase, trypsin and laminarinase. Weight-specific ammonium excretion showed highly significant diel differences, night-time ammonium excretion being 1.7 times that observed at midday. When diel changes in population density are allowed for, the regenerated ammonium flux from female $C$. helgolandicus in the surface $20 \mathrm{~m}$ at midnight is estimated to be 28 times higher than at midday. Gut pigment levels and laminarinase and trypsin activity observed in the might-tıme surface population were consistent with active feeding. Amylase was an exception in showing significantly lower activity at night. Observations at stations characteristic of tidally mixed and frontal conditions showed less pronounced diel changes in metabolism. The implications of these results for competitive interactions between phytoplankton species adapted to pulsed nitrogen supply in nutrient-limited surface waters are considered.
\end{abstract}

\section{INTRODUCTION}

Excretion of ammonium by copepods is important in marine ecosystem dynamics because ammonium is more readily assimilated by most phytoplankton species than nitrate (Glibert et al. 1982); such regenerated nitrogen is essential to maintaining primary production in nitrogen-limited oligotrophic regions (McCarthy \& Goldman 1979). Phytoplankton characteristic of oligotrophic regions can make effective use of short-term exposure to relatively high concentrations of ammonium (McCarthy \& Goldman 1979, Glibert \& Goldman 1981, Goldman et al. 1981). It has been questioned whether pulses of excreted ammonium would persist for long enough, or be large and frequent enough, to be significant for phytoplankton nitrogen uptake (Jackson 1980, Williams \& Muir 1981). In addition to the short term and microscale there is another time-scale on which nutrient pulsing may occur in nutrient-limited waters, that of the diel periodicity related to zooplankton vertical migration. The importance of diel changes in nutrient flux was first proposed by Doyle \& Poore (1974) who suggested that as regenerated nutrient flux is correlated with grazing by zooplankton it should vary cyclically in the euphotic zone. Fluctuations in nutrients might then result in phased cell division with implications for competition between phytoplankton species. Recent laboratory studies have demonstrated the effects of interactions between periodic ammonium supply and light-dark cycles on timing of cell division, experimental nutrient pulsing representing a situation which could result from diel zooplankton grazing rhythms (Olson \& Chisholm 1983, Plumley \& Darley 1985).

Diel periodicity is often observed in many aspects of nitrogen assimilation by phytoplankton, particularly enzyme activities (Collos \& Slawyk 1980). Similarly for zooplankton, methods for measuring aspects of in situ metabolic activity have revealed widespread diel periodicity, particularly of grazing in relation to verti- 
cal migration (Mackas \& Bohrer 1976, Boyd et al. 1980, Dagg \& Grill 1980, Dagg \& Wyman 1983, Nicolajsen et al. 1983, Baars \& Oosterhuis 1984, Head et al. 1984, Mayzaud et al. 1984, Daro 1985, Head et al. 1985 , Landry \& Hassett 1985, Simard et al. 1985). The only studies of diel variations in aspects of metabolism other than feeding are those of Bảmstedt (1984) who used ETS activity to estimate respiration, Duval \& Green (1976) on diel cycles of respiration in freshwater zooplankton and Kleppel et al. (1985) who reported diel variation in body carotenoid content in relation to feeding. Finally, Nott et al. (1985) have recently described cyclical changes in the ultrastructure of the gut of Calanus helgolandicus related to periodicity in digestion.

Evidence consistent with a positive relation between excretion and ingestion of nitrogen has been obtained, for example, by Corner et al. (1965) and Takahashi \& Ikeda (1975), and generally excretion rates decrease once animals are removed from their food (Corner et al. 1965). However, in contrast to these findings Gardner \& Paffenhöfer (1982) reported no significant difference in ammonium release by Eucalanus pileatus over a range of food concentrations, although starving animals had lower rates than well-fed ones. Miller \& Landry (1984) suggest that ammonium excretion by Calanus pacificus is independent of ingestion and point out that ingestion-independent excretion in the short-term in vertically migrating copepods would not conserve nitrogen during the starvation phase of migration other than by a general reduction in metabolic rate from reduced temperature at depth.

The present study was designed to investigate diel periodicity of ammonium release by a population of vertically migrating adult female Calanus helgolandicus in view of its possible importance for phytoplankton in nutrient-limited waters, and because of uncertainties about the relation between feeding and ammonium excretion. The work was conducted in surface stratified waters of the English Channel, an environment where the regenerated nitrogen flux is important in supplying a significant proportion of the surface phytoplankton demand in summer (Holligan et al. $1984 \mathrm{~b})$. Measurements were also made of gut pigments, and the activity of the digestive enzymes amylase, trypsin and laminarinase, which are believed to be indicative of grazing activity. The results of this study are compared with information on vertical migration and zooplankton biomass and gut pigments made under similar conditions in 2 previous years. In addition, a smaller number of observations were made at stations characterized by frontal and tidally mixed conditions (Holligan et al. 1984a) to compare cyclic activity in the $C$. helgolandicus populations of these contrasting hydrographic regimes.

\section{MATERIALS AND METHODS}

The principal observations were carred out during the period 15 to 18 July 1983 under seasonally stratified conditions at Station E5 $\left(49^{\circ} 06^{\prime} \mathrm{N}, 06^{\circ} 30^{\prime} \mathrm{W}\right.$; Fig. 1) in the Western English Channel. Data in support of these observations are also presented for the

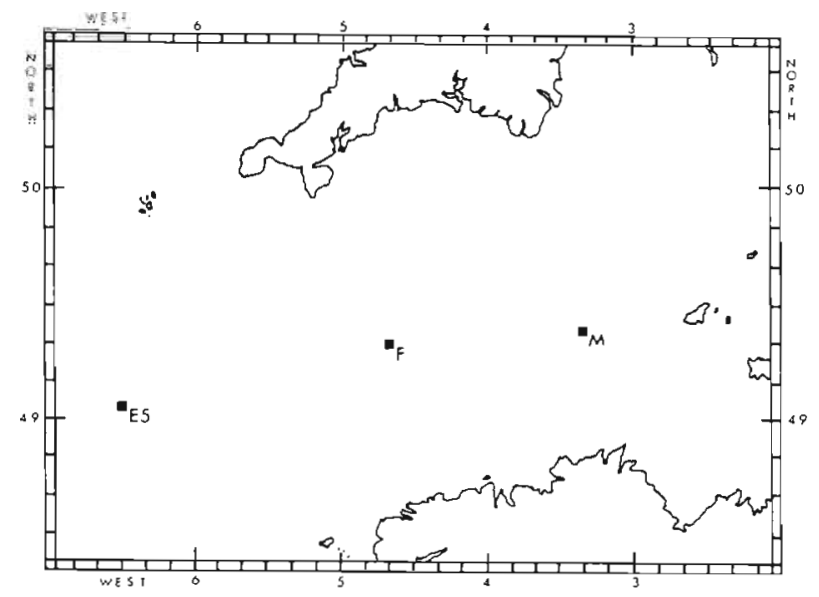

Fig. 1. Positions of stations in stratified (E5), frontal (F) and mixed (M) waters in the western English Channel at which diel cycles were investigated in Jul 1983

same station for September 1979 and August 1982. In July 1983 measurements were also made at tidally mixed (Station $\mathrm{M}, 49^{\circ} 23^{\prime} \mathrm{N}, 03^{\circ} 20^{\prime} \mathrm{W}$ ) and frontal stations (Station F, $49^{\circ} 20^{\prime} \mathrm{N}, 04^{\circ} 40^{\prime} \mathrm{W}$ ). Interpretation of summertime hydrography of the area is given by Pingree et al. (1978).

At each station in 1983 profiles of temperature, salinity and in situ fluorescence were obtained with a Neil Brown CTD system. On the basis of these profiles water samples were collected from 20 and $40 \mathrm{~m}$ with 301 Niskin bottles, between 1000 and $1400 \mathrm{~h}$ (midday) and 2200 and $0200 \mathrm{~h}$ (midnight). The water collected was subsampled for particulate carbon, nitrogen and chlorophyll analyses. Immediately after each bottle cast, replicate vertical hauls were made with a $200 \mu \mathrm{m}$ paired WP-2 net system from $20 \mathrm{~m}$ to the surface. One of the paired net samples was preserved in $5 \%$ formalin for subsequent identification. The contents of the other net were immediately diluted with water containing natural particulate material from $20 \mathrm{~m}$ and transferred to a shipboard constant-temperature room maintained at $15^{\circ} \mathrm{C}$. Here adult female Calanus helgolandicus were rapidly sorted into sea water containing natural particulate material from $20 \mathrm{~m}$ to provide a population of approximately 120 experimental specimens. From this population, within 30 min of capture, 3 subsamples of 10 specimens each were removed and transferred to $5 \mathrm{ml}$ of $90 \%$ acetone for subsequent analysis of gut pigments. A further 3 replicates of 15 
specimens each were removed and frozen for enzyme analysis. From the remaining specimens 3 groups of 10 females were transferred to glass bottles containing $100 \mathrm{ml}$ of $0.2 \mu \mathrm{m}$ filtered sea water for measurement of ammonium excretion. Incubations lasted for 2 to $3 \mathrm{~h}$ in the dark at $15^{\circ} \mathrm{C}$, after which time a subsample of seawater was removed from each experimental and control bottle and immediately analyzed for ammonium by the method of Liddicoat et al. (1975). Experimental specimens were then recovered on a $200 \mu \mathrm{m}$ mesh, counted and dried for subsequent carbon and nitrogen analysis.

Fluorescence of the gut pigment samples was subsequently measured before and after acidification using a Turner fluorometer. The chlorophyll and phaeopigment content of each copepod was calculated using the equations of Dagg \& Wyman (1983), and these 2 values were then summed to give an estimate of the total pigment in the guts. Amylase, trypsin and protein were estimated with an adapted automated method (Samain et al. 1977) and laminarinase activity using the procedure given by Harris et al. (1985). The carbon and nitrogen content of the Calanus helgolandicus and the particulate samples were measured with a Carlo Erba model $1106 \mathrm{CHN}$ analyzer.

In September 1979, the depth distribution of Calanus helgolandicus was sampled at discrete depth intervals $(10 \mathrm{~m})$ over a $24 \mathrm{~h}$ period at E5 using a submersible pump system (Holligan et al. 1984a). Specimens were immediately removed from these samples and placed in $90 \%$ acetone for gut pigment analysis. In August 1982 , the vertical distribution of zooplankton nitrogen in the surface $60 \mathrm{~m}$ by day and by night at E5 was measured using the pump system as described by Holligan et al. (1984a). Briefly the intake hose was raised from $60 \mathrm{~m}$ to $2 \mathrm{~m}$ in steps of $2 \mathrm{~m} \mathrm{~min}^{-1}$. The flow over 5 integrated depth intervals was sequentially filtered through $200 \mu \mathrm{m}$ and $80 \mu \mathrm{m}$ mesh nets. The material retained by these nets was subsampled and deep frozen for subsequent nitrogen analysis.

\section{RESULTS}

\section{Stratified conditions: E5, July 1983}

In July 1983, Station E5 was well-stratified with a $6.7 \mathrm{C}^{\circ}$ temperature difference across the thermocline, which occurred at a depth of about $24 \mathrm{~m}$ (Table 1). Consistent with the degree of stratification, levels of chlorophyll and particulate carbon and nitrogen (Table 1) were about 3 times higher in the warm surface waters $(20 \mathrm{~m})$ than they were below the thermocline $(40 \mathrm{~m})$.

The age structure of Calanus helgolandicus in samples differed between day and night (Fig. 2). There was a highly significant increase in the density of adult females at night. Copepodid Stages I to IV occurred at low concentrations, and there were no significant differences between their day and night densities. The average density of copepodid Stage $\mathrm{V}$ was twice as high at night as during the day, but this difference was not significant. The strong diel cycle in numbers of females in surface waters is further illustrated in Fig. 3

Table 1. Hydrographic observations, and levels of chlorophyll, particulate carbon and nitrogen sampled above (20 m) and below $(40 \mathrm{~m})$ the thermocline at stratified (E 5) frontal (F) and mixed water (M) stations during Jul 1983. Values for particulate material are means of midday and midnight values with $95 \%$ confidence limits in parentheses

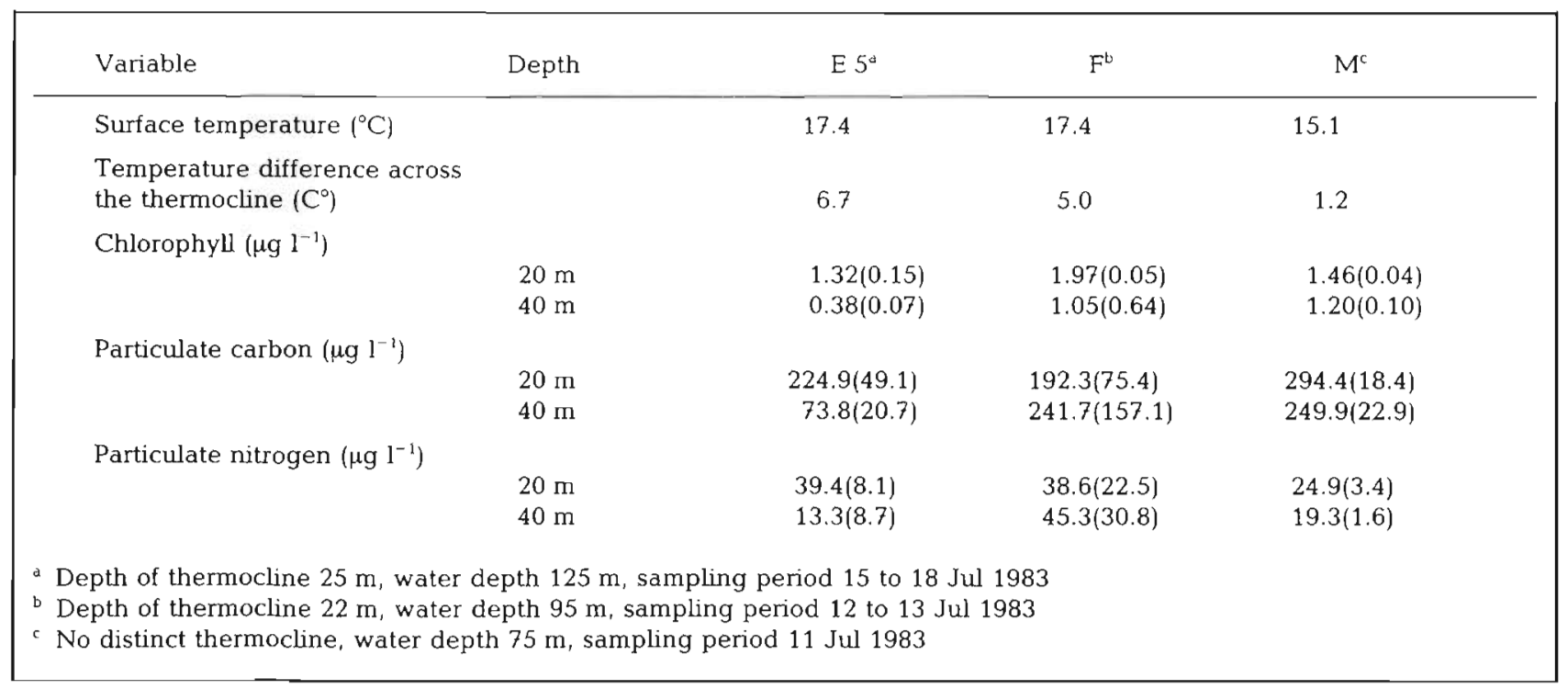




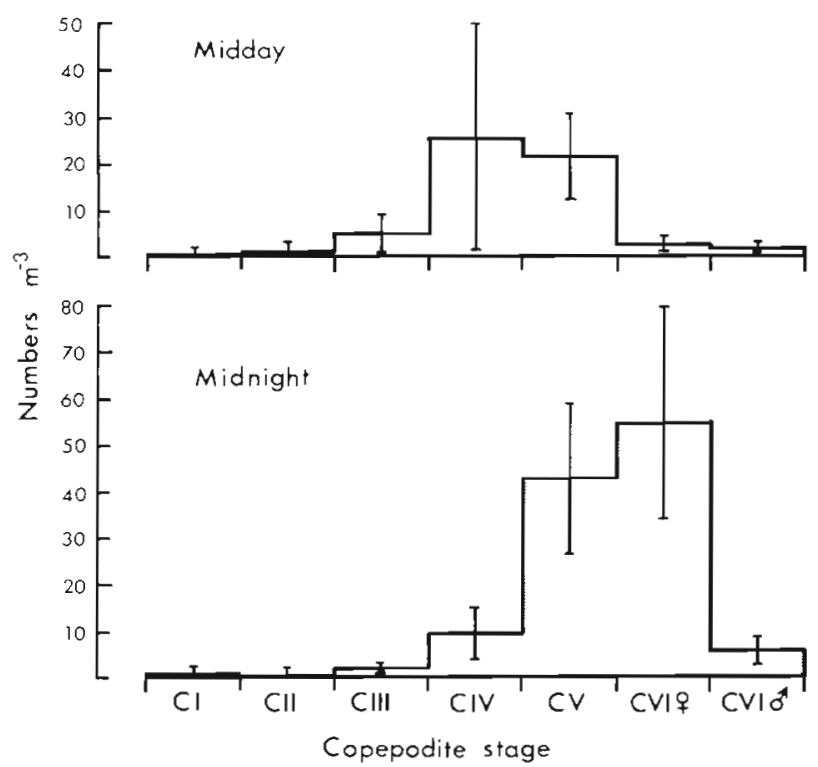

Fig. 2. Calanus helgolandicus. Numbers of each copepodite stage observed in the upper $20 \mathrm{~m}$ of the water column at E5 based on the average of 6 midday and 6 midnight samples during Jul 1983. Vertical bars: $95 \%$ confidence limits. Day and night densities for $\mathrm{CI}$ to $\mathrm{CV}$ and CVI of were not significantly different at $p<0.05$. Midnight densities of CVI $q$ were significantly higher than midday $(p<0.01)$

where mean population estimates for the surface $20 \mathrm{~m}$ are shown for midday and midnight over the $3 \mathrm{~d}$ study period in July 1983. There was a highly significant difference in abundance between each successive pair of day and night observations. The average midnight abundance was over 17 times higher than that for midday observations (Table 2).

Excretion by adult females captured in the upper $20 \mathrm{~m}$ by day and by night is shown in Fig. 3. Ammonium excretion was obviously higher at night when compared with specimens present in the same depth stratum by day. Three of the 4 day-night pairs of observations were significantly different at $p<0.05$, and in 2 cases at $p<0.01$. The ammonium nitrogen excreted, calculated on a daily basis, represented $3.9 \%$ of the body nitrogen on average by day and $6.4 \%$ at night, an increase by a factor of $1.7 \mathrm{in}$ the night-time population (Table 2).

The gut pigment was similarly significantly higher at night than by day when data for the whole study period are pooled (Table 2). The average night-time level was 25 times higher than observed during the day. However, the gut pigment data (Fig. 4) were much more variable than some of the other metabolic parameters measured and only one of the sequential daynight pairs of observations was significantly different.

The activity of digestive enzymes showed significant diel differences (Fig. 4). These were most prominent for laminarinase where the average level in copepods
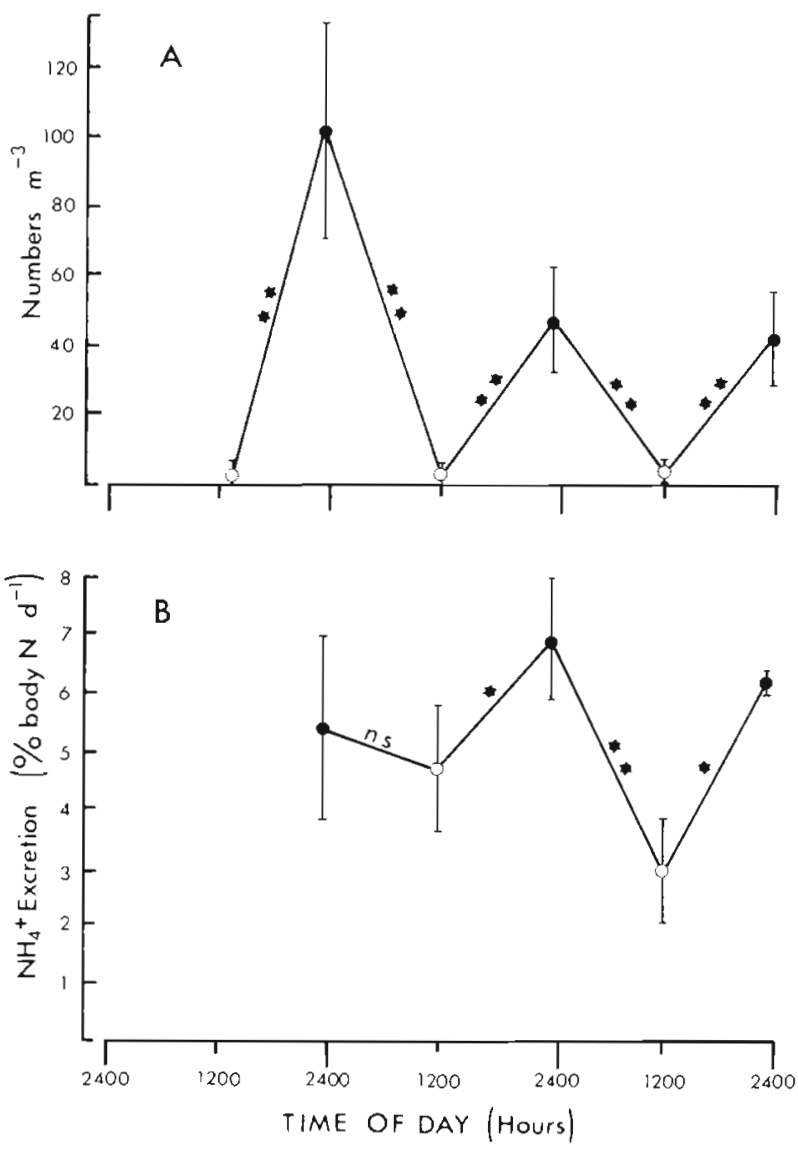

Fig. 3. Calanus helgolandicus adult females. (A) Mean values of density, and (B) weight-specific ammonium excretion, for the upper $20 \mathrm{~m}$ of the water column at E5 over $3 \mathrm{~d}$ in Jul 1983 (O) midday estimates; $(\bullet$ ) midnight estimates. Vertical bars: $95 \%$ confidence limits. $\star \star$ consecutive means are significantly different at $p<0.01 ; \star$ at $p<0.05 ;$ ns: consecutive mean values not significantly different

at night was 1.5 times higher than in the day (Table 2). Four out of 5 sequential day-night pairs were significantly different, in 3 cases at the $p<0.01$ level. Trypsin exhibited a similar cyclical pattern with higher levels at night followed by lower levels by day, but none of the consecutive pairs were significantly different. However, pooled values for all the night samples were significantly higher than those by day at the $p<0.05$ level. Amylase also showed a cyclical pattern but the inverse of the other enzymes with higher activity by day than by night. Three sequential day-night pairs were significantly different (Fig. 4) and the mean of the pooled night values differed from that for the day samples at the $p<0.01$ level.

Frontal and mixed conditions: F and M, July 1983

Paired day and night samples and ammonium excretion experiments were also carried out over $24 \mathrm{~h}$ 
Table 2. Calanus helgolandicus. Means densities, at midday and midnight, of adult females in the upper $20 \mathrm{~m}$ at E 5 in Jul 1983 , and mean values for the measures of metabolic activity of individual females observed in these populations. Figures in parentheses: $9.5 \%$ confidence limits

\begin{tabular}{|c|c|c|c|c|c|}
\hline & Variable & Midday & Midnight & Night/Day & Significance \\
\hline & $\begin{array}{l}\text { Population density } \\
\quad \text { (ind } \mathrm{m}^{-3} \text { ) }\end{array}$ & $3.1(1.7)$ & $55.2(21.0)$ & 17.6 & $\cdots$ \\
\hline & $\begin{array}{l}\text { Level of total gut } \\
\text { pigment (ng) }\end{array}$ & $0.06(0.02)$ & $1.50(0.73)$ & 25.0 & $\cdots$ \\
\hline & $\begin{array}{l}\text { Specific amylase } \\
\text { activity }(\mathrm{A} / \mathrm{P})^{\mathrm{b}}\end{array}$ & $0.31(0.05)$ & $0.20(0.02)$ & 0.6 & $\cdots$ \\
\hline & $\begin{array}{l}\text { Specific trypsin } \\
\text { activity }(\mathrm{T} / \mathrm{P})^{\mathrm{b}}\end{array}$ & $5.24(1.11)$ & $6.64(0.67)$ & 1.3 & $\cdot$ \\
\hline & $\begin{array}{l}\text { Specific laminarinase } \\
\text { activity }(\mathrm{L} / \mathrm{P})^{\circ}\end{array}$ & $16.8(1.8)$ & $24.7(2.2)$ & 1.5 & $\cdots$ \\
\hline & $\begin{array}{l}\text { Body nitrogen } \\
\qquad\left(\mu \text { copepod }^{-1}\right)\end{array}$ & $16.7(0.7)$ & $17.4(0.6)$ & 1.0 & ns \\
\hline & $\begin{array}{l}\text { Ammonium excretion } \\
\quad\left(\mu \mathrm{g} \mathrm{NH} \mathrm{N}_{4}-\mathrm{N} \text { copepod }{ }^{-1} \mathrm{~h}^{-1}\right)\end{array}$ & $0.027(0.007)$ & $0.045(0.009)$ & 1.7 & $\cdot$ \\
\hline & $\begin{array}{l}\text { Weight specific excretion } \\
\text { rate }\left(\% \text { body } \mathrm{N} \mathrm{d}^{-1}\right)\end{array}$ & $3.85(1.27)$ & $6.42(1.28)$ & 1.7 & $\cdots$ \\
\hline \multicolumn{6}{|c|}{$\begin{array}{l}\text { ' Ratio of midnight to midday values } \\
\text { b Enzyme units as in legend to Fig. } 4 \\
\text { - Significant difference between midday and midnight values at } p<0.01 \text {; 'significance at } p<0.05 \text {; ns: not significant }\end{array}$} \\
\hline
\end{tabular}

periods during July 1983 at stations characterized by frontal $(F)$ and tidally mixed regimes (M) shown in Fig. 1. Female Calanus helgolandicus were less abundant at both of these stations compared with E5. At neither $F$ or $M$ was there a significant difference in the upper $20 \mathrm{~m}$ between day and night, although it should be noted that sampling variability was higher than at E5. Average day and night values for each of the metabolic parameters for these 2 stations are summarized in Table 3. At $M$ there were no significant differences between day and night levels for any of the indices of grazing activity. Levels of laminarinase appeared higher than at E5 while levels of trypsin were more comparable to those at the stratified station. Levels of gut pigment at $M$ were higher at night, but the difference was not significant. In contrast, there was a highly significant difference in the rates of ammonium excretion per copepod. However, as specimens collected at night had higher levels of body nitrogen the weight specific excretion rate (Table 3 ) did not differ between day and night. The rate was considerably higher than at the stratified station, representing about $9 \%$ of the body nitrogen expressed on a daily basis.

At the frontal station excretion rates were similar to those under tidally mixed conditions, and although excretion was higher at night by a factor of 1.2 this difference was not significant. Gut pigment levels were low both by day and by night. None of the 3 digestive enzymes showed significant day-night differences, but in each case the pattern was similar to that at E5 with higher levels of trypsin and laminarinase at night, and the inverse in the case of amylase. The activity of amylase was the highest at this station.

\section{Stratified conditions: E5, September 1979}

In September 1979 measurements were made at E5 of the vertical distribution of the Calanus helgolandicus population and gut pigments for discrete samples taken at $10 \mathrm{~m}$ intervals with a pump system over a $24 \mathrm{~h}$ period. The results are presented in Fig. 5, and are essentially consistent with the observations for the 0 to $20 \mathrm{~m}$ population made at midday and midnight in July 1983, which have already been described. Higher numbers of females were present in surface waters at night, and these specimens were characterized by elevated levels of gut pigments, considerably higher than those observed in July 1983. By day females moved below the thermocline, with a concurrent decrease in pigment levels in the day-time population which was concentrated at about $40 \mathrm{~m}$. 

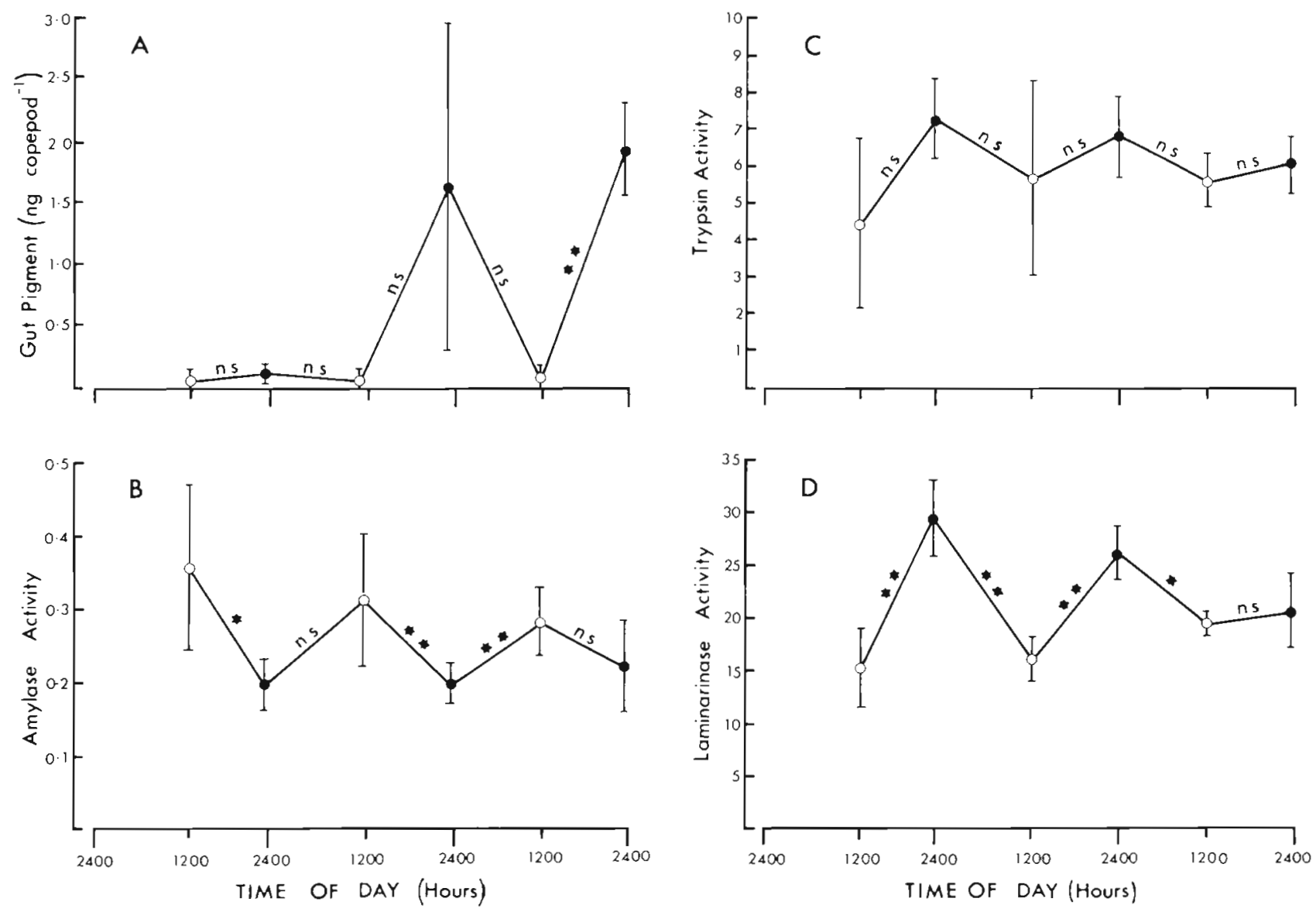

Fig. 4. Calanus helgolandicus adult females. Mean values of (A.) gut pigment, (B) amylase activity, (C) trypsin activity, and (D) laminarinase activity in the upper $20 \mathrm{~m}$ of the water column at E5 over $3 \mathrm{~d}$ in Jul 1983 . Units of enzyme activity are as follows: amylase, $\mathrm{mg}$ starch degraded $\mathrm{min}^{-1}$ (mg body protein) ${ }^{-1}$; trypsin, units (mg body protein) ${ }^{-1}$, where units are $\mu \mathrm{mgl}^{-1}$ of trypsin Merck No 8214; laminarinase, mg equivalent glucose $\min ^{-1} \times 10^{-3}$, (mg body protein) $^{-1}$. (O) midday estimates; $(\bullet)$ midnight estimates. Vertical bars: $95 \%$ confidence limits. $\star$ consecutive means significantly different at $p<0.01 ; \star$ at $p<0.05 ;$ ns: consecutive mean values not significantly different

\section{Stratified conditions: E5, August 1982}

An indication of the relative importance of the adult female Calanus helgolandicus as a component of the zooplankton biomass at E5 in summer is illustrated in Fig. 6 for data obtained in August 1982. Again there are clear day-night changes in distribution for the adult population, maximum densities occurring in the 2 to $12 \mathrm{~m}$ interval by night and between 36 and $48 \mathrm{~m}$ by day. Similar diel changes were observed for the total mesozooplankton biomass, and there was some evidence of migration by the microzooplankton 180 to $200 \mu \mathrm{m}$ ). From Table 4 , it can be seen that adult female C. helgolandicus formed $10 \%$ of the total zooplankton biomass at the surface by night, being equivalent to over $40 \%$ of the total 80 to $200 \mu \mathrm{m}$ microzooplankton nitrogen. By day below the thermocline (36 to $48 \mathrm{~m}$ ) adult females again were the equivalent of over $40 \%$ relative to the microzooplankton biomass, and about $18 \%$ of the total zooplankton greater than $80 \mu \mathrm{m}$.

\section{DISCUSSION}

During the present study we observed strong diel fluctuations in the surface concentrations of adult female Calanus helgolandicus in stratified waters, consistent with vertical migration from depths below the thermocline at night. The presence of active diel migration through the thermocline is supported by results from 2 previous studies at this station at the same time of year (Fig. $5 \& 6$ ). Higher rates of weight specific ammonium excretion, elevated levels of gut pigments, and higher laminarinase and trypsin activity were observed in the population present in these stratified surface waters by night when compared with 
Table 3. Calanus helgolandicus. Comparison of mean densities, at midday and midnight, of adult females in the upper $20 \mathrm{~m}$ at mixed (M) and frontal (F) stations in Jul 1983, and mean values for the measures of metabolic activity of individual females observed in these populations. Figures in parentheses: $95 \%$ confidence limits

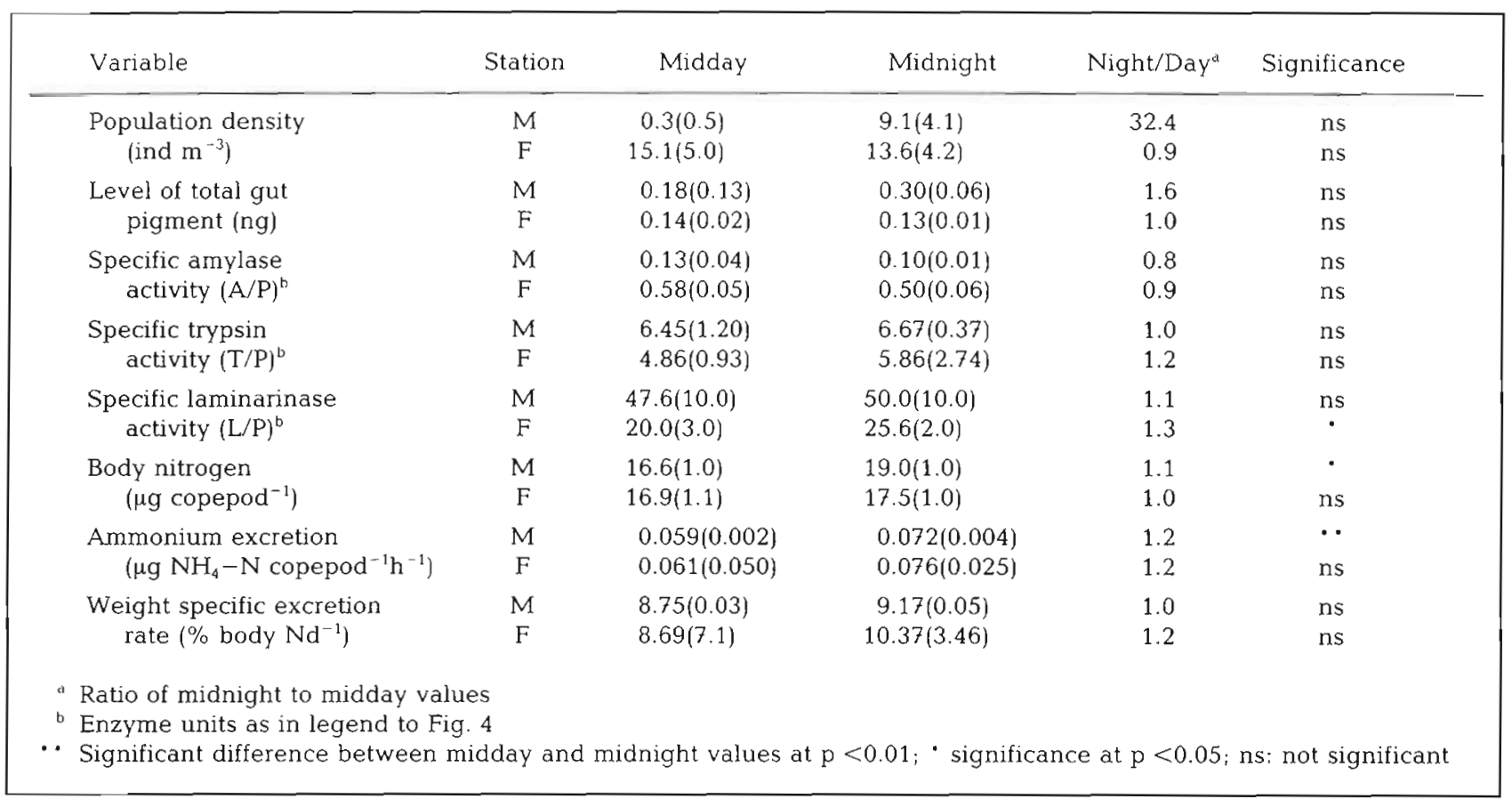

Fig. 5. Calanus helgolandicus adult females. E5, Sep 1979. Density (upper) and level of pigment in guts (lower) for the upper $60 \mathrm{~m}$ of the water column over a $24 \mathrm{~h}$ cycle. Stippled regions indicate population densities above 50 females $\mathrm{m}^{-3}$, and levels of gut pigment above $5 \mathrm{ng}$ copepod $^{-1}$. Thermocline depth $25 \mathrm{~m}$, temperature difference across thermocline $5.20 \mathrm{C}^{\circ}$
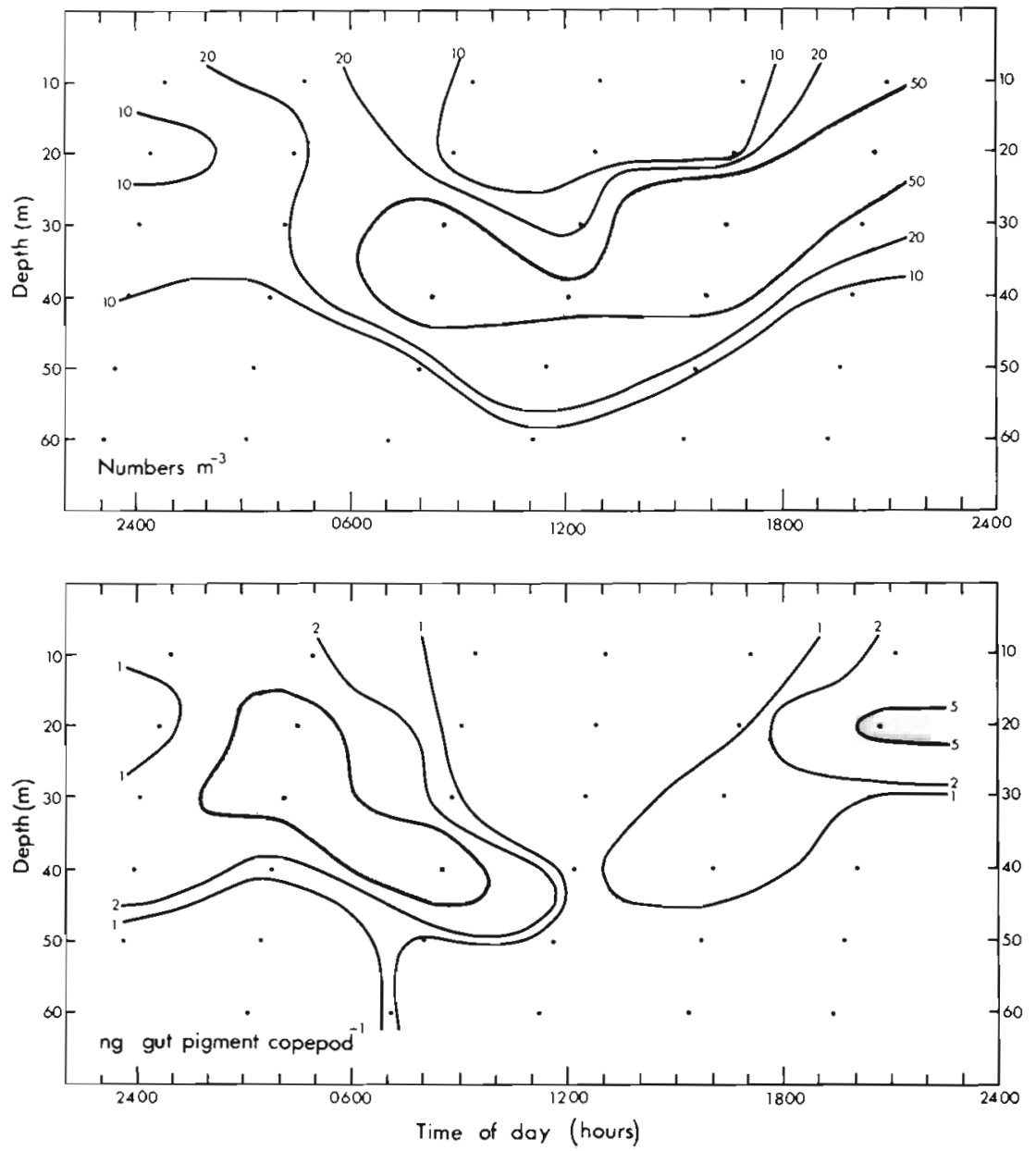


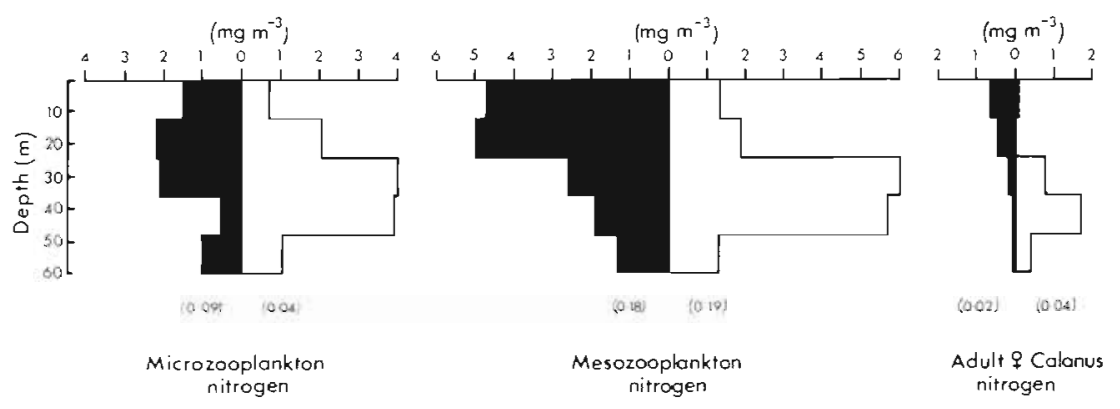

Fig. 6. Calanus helgolandicus adult females. E5, Jul 1982. Vertical distribution expressed as nitrogen biomass, compared with microzooplankton (80 to $200 \mu \mathrm{m}$ ) and mesozooplankton (>200 $\mu \mathrm{m}$ ) nitrogen biomass for equivalent depth intervals. Black: midnight distribution; white: midday. Values in parentheses: integrated standing stock in the upper $60 \mathrm{~m}$ as $\mathrm{g} N \mathrm{~m}^{-2}$. Thermocline depth $24 \mathrm{~m}$, temperature difference across thermocline $7.24 \mathrm{C}^{\circ}$

Table 4. Calanus helgolandicus. Adult female nitrogen biomass represented as a percentage of microzooplankton, mesozooplankton and total zooplankton nitrogen biomass measured in 5 depth intervals in the upper $60 \mathrm{~m}$ at $\mathrm{E} 5$ at midday and midnight on 8-9 Aug 82. Percentages determined from the product of the counts illustrated in Fig. 6 , and the mean body nitrogen, $17.1 \mu \mathrm{g}$ female ${ }^{-1}$

\begin{tabular}{|c|c|c|c|c|c|c|}
\hline \multirow[t]{2}{*}{ Depth (m) } & \multicolumn{2}{|c|}{ Microzooplankton ${ }^{\alpha} \mathrm{N}$} & \multicolumn{2}{|c|}{ Mesozooplankton ${ }^{\mathrm{b}} \mathrm{N}$} & \multicolumn{2}{|c|}{ Total zooplankton ${ }^{\mathrm{C}} \mathrm{N}$} \\
\hline & Midday & Midnight & Midday & Midnight & Midday & Midnight \\
\hline $2-12$ & 1.1 & 42.1 & 6.0 & 13.7 & 3.9 & 10.3 \\
\hline $12-24$ & 2.9 & 20.7 & 3.2 & 9.0 & 1.5 & 6.3 \\
\hline $24-36$ & 19.3 & 6.5 & 12.8 & 5.5 & 7.7 & 3.0 \\
\hline $36-48$ & 43.6 & 0.4 & 30.5 & 1.1 & 17.9 & 0.8 \\
\hline $48-60$ & 3.4 & 5.9 & 2.7 & 4.7 & 10.9 & 2.6 \\
\hline $\begin{array}{l}\text { a } 80 \text { to } 200 \mu \mathrm{m} \text { size } \\
\Rightarrow>200 \mu \mathrm{m} \text { size fra } \\
\Rightarrow>80 \mu \mathrm{m} \text { size fract }\end{array}$ & & & & & & \\
\hline
\end{tabular}

the much smaller number of copepods present at the surface during the day. The presence of pronounced migratory behaviour implies that either endogenous diel feeding rhythms occur in the surface population unrelated to migration, or that 2 different populations are present in the stratified water column with distinct metabolic characteristics, one migratory, and one residing continuously in the surface layers.

The problem of identifying intrinsic rhythms in copepods which also exhibit strong diel vertical migration has concerned workers in many investigations since the early studies by Gauld (1953). The development of in situ techniques for estimating grazing related parameters such as gut pigments (Mackas \& Bohrer 1976) and digestive enzyme activity (Boucher \& Samain 1974) has enabled studies to be made of cyclic feeding activity in field populations. Most investigators have relied on taking simultaneous samples from a number of depths to attempt to discriminate between cyclical rhythms and vertical migration. However, few studies have included concurrent estimates of population density to demonstrate the actual pattern of migration occurring within the population. In any case, as has been pointed out by Pearre (1979), there may still be considerable problems of interpretation if there is a dynamic exchange of individuals between the surface and deeper water.

The day-night differences in gut pigment which we observed at E5 are similar to those in a wide variety of other studies, on a variety of species of copepods, and under a range of hydrographic conditions (Hayward 1980, Nicolajsen et al. 1983, Baars \& Oosterhuis 1984, Head et al. 1984, Mayzaud et al. 1984, Daro 1985). In general, the pigment levels in the gut have been interpreted as being related to ingestion (Mackas \& Bohrer 1976, Dagg \& Grill 1980, Dagg \& Wyman 1983) but the actual relation between gut pigments and migratory behaviour remains somewhat uncertain (Head et al. 1985). A number of studies have indicated quite complex feeding patterns indicative of short-term intermittent feeding (Boyd et al. 1980, Simard et al. 1985), suggesting that the most important variable determining both the patterns of diurnal feeding of copepods and their migratory behaviour is the concentration of food available to them, a conclusion which is supported by the results of Dagg (1985). 
$80 \mu \mathrm{g}$ ash-free dry weight. Hence, there remain uncertainties about the relative excretory rates of the smaller zooplankton although as small copepods are generally more numerous their contribution to the regenerated flux may be great. For example, at E5 the total population of $P$. parvus in the upper $20 \mathrm{~m}$ in July 1983 averaged $1400 \mathrm{~m}^{-3}$, with no significant difference being observed between the densities at midday and midnight. Using the value for excretion by $P$. parvus given by Holligan et al. (1984b) an estimate can be made of the regeneration by these small copepods relative to $C$. helgolandicus (Table 5). Clearly, it is in areas where large migratory copepods predominate that diel periodicity in nitrogen flux will be greatest, though more work needs to be done on possible diel cycles within the microzooplankton.

Despite these uncertainties the hypothesis that ammonium is supplied rhythmically by zooplankton excretion is supported by our observations in surface stratified waters. This finding supports the relevance of laboratory investigations on the interactions between nitrogen pulsing and photoperiod to field situations of nitrogen limitation (Yoder et al. 1982, Olson \& Chisholm 1983, Plumley \& Darley 1985). Doyle \& Poore (1974) first suggested that fluctuating nitrogen regimes might result in a phasing of phytoplankton cell division. Subsequently such induction of division synchrony has been reported in nitrogen-limited diatom cultures subjected to daily pulses of nitrate (Yoder et al. 1982) and interaction of light-dark cycles and pulses of nitrogen including ammonium have been investigated by Olson \& Chisholm (1983) and by Plumley \& Darley (1985).

These laboratory studies have indicated the significant effect nitrogen pulsing may have on cell division patterns in phytoplankton populations. It is the importance of such pulsed nutrient supply for interspecific competition for nutrients within the phytoplankton which deserves particular consideration, as fluctuating nitrogen regimes have been shown to affect the outcome of competition in continuous cultures of natural phytoplankton (Turpin \& Harrison 1979). In particular, the findings of Paasche et al. (1984), that some dinoflagellates such as Gyrodinium aureolum have a near absolute light requirement for nitrogen uptake whereas others do not, are most relevant to our own results. G. aureolum is a dominant summer species in frontal conditions and in the subsurface chlorophyll maximum in stratified waters in the English Channel (Holligan et al. 1983, 1984a, b). Clearly, the findings of Paasche et al. (1984) coupled with an appreciation of the proportion of the ammonium regeneration flux which occurs at night, and is therefore only available to competing species, will affect the estimation of nitrogen supply to these dinoflagellate populations in frontal and stratified waters. The interaction between light-dark cycle, diel migration of both phytoplankton and zooplankton, and diel cycles of zooplankton excretion and nitrogen uptake by phytoplankton, will have considerable implications for feedback between zooplankton and phytoplankton in thermally stratified waters.

Acknowledgements. We thank Dr. J. F. Samain and J. Y. Daniel for undertaking the analysis of digestive enzyme samples and for helpful comments on the manuscript. R. N. Head and P. R. G. Tranter assisted with the ammonium analyses and zooplankton counts, respectively. Linda Mavin provided outstanding technical assistance at sea. Financial support for this project was received from the Ministry of Agriculture, Fisheries and Food (U.K.).

\section{LITERATURE CITED}

Baars, M. A., Oosterhuis, S. S. (1984). Diurnal rhythms in grazing on labelled food, gut fluorescence and digestive enzyme activities of North Sea copepods. Neth. J. Sea Res. 18: $97-119$

Båmstedt, U. (1984). Diel variations in the nutritional physiology of Calanus glacialis from Lat. $78^{\circ} \mathrm{N}$ in the summer. Mar. Biol. 79: 257-267

Boucher, J., Samain, J. F. (1974). L'activité amylasique indice de la nutrition du zooplancton, mise en évidence d'un rhythme quotidien en zone d'upwelling. Téthys 6: 179-188

Boyd, C. M., Smith, S. L., Cowles, T. J. (1980). Grazing patterns of copepods in the upwelling system of Peru. Limnol. Oceanogr. 25: 583-596

Collos, Y., Slawyk, G. (1980). Nitrogen uptake and assimilation by marine phytoplankton. In: Falkowski, P. G. (ed.) Primary productivity in the sea. Plenum Press, New York, p. $195-211$

Corkett, C. J., McLaren, I. A. (1978). The biology of Pseudocalanus. Adv. mar. Biol. 15: 1-231

Corner, E. D. S., Cowey, C. B., Marshall, S. M. (1965). On the nutrition and metabolism of zooplankton. 3. Nitrogen excretion by Calanus. J. mar. biol. Ass. U.K. 45: 429-142

Dagg, M. J. (1985). The effects of food limitation on diel migratory behaviour in marine zooplankton. Arch. Hydrobiol. Beih. Ergeb. Limnol. 21: 247-255

Dagg, M. J., Grill, D. W. (1980). Natural feeding rates of Centropages typicus females in the New York Bight. Limnol. Oceanogr. 25: 597-609

Dagg, M. J., Wyman, K. D. (1983). Natural ingestion rates of the copepods Neocalanus plumchrus and N. cristatus calculated from gut contents. Mar. Ecol. Prog. Ser. 13: 37-46

Daro, M. H. (1985). Feeding rhythms and vertical migration of marine copepods. Bull. mar. Sci. 37: 487-497

Doyle, R. W., Poore, R. V. (1974). Nutrient competition and division synchrony in phytoplankton. J. exp. mar Biol. Ecol. 14: 201-210

Duval, W. S., Green, G. H. (1976). Diel feeding and respiration rhythms in zooplankton. Limnol. Oceanogr. 21: 823-829

Gardner, W. S., Paffenhöfer, G.-A. (1982). Nitrogen regeneration by the subtropical marine copepod Eucalanus pileatus. J. Plankton Res. 4: 725-734

Gauld, D. T. (1953). Diumal variations in the grazing of planktonic copepods. J. mar. biol. Ass. U.K. 31 461-474 
Glibert, P. M., Goldman, J. C. (1981). Rapid ammonium uptake by marine phytoplankton. Mar. Biol. Lett. 2: 25-31

Glibert, P. M., Biggs, D. C., McCarthy, J. J. (1982). Utilization of ammonium and nitrate during austral summer in the Scotia Sea. Deep Sea Res. 29: 837-850

Goldman, J. C., Dennett, M. R., Riley, C. B. (1981). Marine phytoplankton photosynthesis and transient ammonium variability. Mar. Biol. Lett. 2: 323-331

Harris, R. P., Samain, J. F., Moal, J., Martin-Jezequel, V., Poulet, S. A. (1985). Effects of algal diet on digestive enzyme activity in Calanus helgolandicus. Mar. Biol. 90: 353-361

Hayward, T. L. (1980). Spatial and temporal feeding patterns of copepods from the North Pacific Central Gyre. Mar. Biol. 58: 295-309

Head, E. J. H., Wang, R., Conover, R. J. (1984). Comparison of diurnal feeding rhythms in Temora longicornis and Centropages hamatus with digestive enzyme activity. J. Plankton Res. 6: 543-551

Head, E. J. H., Harris, L. R., Abou Debs, C. (1985). Effect of daylength and food concentration on in situ diurnal feeding rhythms in Arctic copepods. Mar. Ecol. Prog. Ser. 24: 281-288

Holligan, P. M., Viollier, M., Dupouy, C., Aiken, J. (1983). Satellite studies on the distribution of chlorophyll and dinoflagellate blooms in the western English Channel. Contin. Shelf Res. 2: 81-96

Holligan, P. M., Harris, R. P., Newell, R. C., Harbour, D. S., Head, R. N., Linley, E. A. S., Lucas, M. I., Tranter, P. R. G., Weekley, C. M. (1984a). Vertical distribution and partitioning of organic carbon in mixed, frontal and stratified waters of the English Channel. Mar. Ecol. Prog. Ser. 14: $111-127$

Holligan, P. M., Williams, P. J. leB., Purdie, D., Harris, R. P. (1984b). Photosynthesis, respiration and nitrogen supply of plankton populations in stratified, frontal and tidally mixed shelf waters. Mar. Ecol. Prog. Ser. 17: 201-213

Jackson, G. A. (1980). Phytoplankton growth and zooplankton grazing in oligotrophic oceans. Nature, Lond. 284: $439-441$

Kleppel, G. S., Willbanks, L., Pieper, R. E. (1985). Diel variation in body carotenoid content and feeding activity in marine zooplankton assemblages. J. Plankton Res. 7: $569-580$

Landry, M. R., Hassett, R. R. (1985). Time scales in behavioural, biochemical, and energetic adaptations to foodlimiting conditions by a marine copepod. Arch. Hydrobiol. Beih. Ergeb. Limnol. 21: 209-221

Liddicoat, M. I., Tibbits, S., Butler, E. I. (1975). The determination of ammonia in sea water. Limnol. Oceanogr. 20: $131-132$

Mackas, D., Bohrer, R. (1976). Fluorescence analysis of zooplankton gut contents and an investigation of diel feeding patterns. J. exp. mar. Biol. Ecol. 25: 77-85

Mayzaud, O., Mayzaud, P., de la Bigne, C., Grohan, P., Conover, R. J. (1984). Diel changes in the particulate environment, feeding activity and digestive enzyme concentration in neritic zooplankton. J. exp. mar. Biol. Ecol. 84: 15-35

McCarthy, J. J., Goldman, J. C. (1979). Nitrogenous nutrition of marine phytoplankton in nutrient depleted waters. Science 203: 670-672

Miller, C. A., Landry, M. R. (1984). Ingestion-independent rates of ammonium excretion by the copepod Calanus pacificus. Mar. Biol. 78: 265-270

Nicolajsen, H., Mølenberg, F., Kiørboe, T (1983). Algal grazing by the planktonic copepods Centropages hamatus and Pseudocalanus sp. Diumal and seasonal variation during the spring phytoplankton bloom in the Øresund. Ophelia 22: $15-31$

Nott, J. A., Corner, E. D. S., Mavin, L. J., O'Hara, S. C. M. (1985). Cyclical contributions of the digestive epithelium to faecal pellet formation by the copepod Calanus helgolandicus. Mar. Biol. 89: 271-279

Olson, R. J., Chisholm, S. W. (1983). Effects of photocycles and periodic ammonium supply on three marine phytoplankton species. I. Cell division patterns. J. Phycol. 19: $522-528$

Paasche, E., Bryceson, I., Tangen, K. (1984). Interspecific variation in dark nitrogen uptake by dinoflagellates. J. Phycol. 20: 394-401

Paffenhöfer, G.-A., Gardner, W. S. (1984). Ammonium release by juveniles and adult females of the subtropical marine copepod Eucalanus pileatus. J. Plankton Res. 6: 505-513

Pearre, S. (1979). Problems of the detection and interpretation of vertical migration. J. Plankton Res. 1: 29-44

Pingree, R. D., Holligan, P. M., Mardell, G. T. (1978). The effects of vertical stability on phytoplankton distributions in the summer on the northwest European shelf. Deep Sea Res. 25: 1011-1028

Plumley, F. G., Darley, W. M. (1985). Interactions of light/dark cycles and nitrogen pulses on the timing of cell division in the nitrogen-limited marine diatom Cylindrotheca fusiformis (Bacillariophyceae). J. Phycol. 21: 25-34

Samain, J. F., Daniel, J. Y., LeCoz, J. R. (1977). Trypsine, amylase et proteines du zooplancton: dosages automatique et manuel. J. exp. mar. Biol. Ecol. 29: 279-289

Simard, Y., Lacroix, G., Legendre, L. (1985). In situ twilight grazing rhythm during diel vertical migrations of a scattering layer of Calanus finmarchicus. Limnol. Oceanogr. 30: 598-606

Takahashi, M., Ikeda, T. (1975). Excretion of ammonia and inorganic phosphorus by Euphausia pacifica and Metridia pacifica at different concentrations of phytoplankton. J. Fish. Res. Bd Can. 32: 2189-2199

Tande, K. S., Slagstad, D. (1982). Ecological investigations on the zooplankton community of Balsfjorden, Northern Norway. Seasonal and short-time variations in enzyme activity in copepodite stage V and VI males and females of Calanus finmarchicus (Gunnerus). Sarsia 67: 63-68

Turpin, D. H., Harrison, P. J. (1979). Limiting nutrient patchiness and its role in phytoplankton ecology. J. exp. mar. Biol. Ecol. 39: 151-166

Williams, P. J. leB., Muir, L. R. (1981). Diffusion as a constraint on the biological importance of microzones in the sea. In: Nihoul, J. C. J. (ed.) Ecohydrodynamics. Elsevier, Amsterdam, p. 209-218

Yoder, J. A., Martin, J., Nill, A. (1982). Cell division periodicity and the nitrate environment of a marine diatom. Limnol. Oceanogr. 27: 352-357 